\title{
ВИДАВНИЧИЙ ДІЯЛОГ З УКРАЇНСЬКИМ СУСПІЛЬСТВОМ В УМОВАХ ПОЛЬСЬКОЇ ВЛАДИ (НА ПРИКЛАДІ ВИДАНЬ І. ТИКТОРА ТА ТОВАРИСТВА "ПРОСВІТА")
}

\author{
Марія ПІРКО, Алла СЕРЕДЯК \\ Львівський національний університет імені Івана Франка \\ кафедра історичного краєзнавства \\ вул. Університетська, 1, Львів, 79000, Україна \\ mariya.pirko@gmail.com,_aserediak@yahoo.com
}

На основі друкованої продукції товариства "Просвіта" та концерну І. Тиктора "Українська Преса" у статті проаналізовано тематику видань двох потужних видавничих центрів Галичини міжвоєнного періоду. Висвітлено напрями їхньої співпраці, шляхи книгорозповсюдження, орієнтованість тематики видань на читацькі інтереси. Зроблено спробу з'ясувати вплив видавничого масиву організацій, щоб залучати українське населення споживати друковане слово рідною мовою, налагоджувати діялог “видавець-читач”, формувати свідомість українців, що після поразки Визвольних змагань опинилися у складі Польської держави.

Ключові слова: товариство "Просвіта", Іван Тиктор, концерн "Українська Преса", українські друки, національна свідомість.

Повоєнна розруха та поразка української революції поставила населення західноукраїнських земель перед необхідністю вирішувати націотворчі завдання в нових, складніших умовах. Уряд Другої Речі Посполитої відкрито проводив антиукраїнську політику. Усі чинні інституції ЗУНР були ліквідовані, польська влада скасувала Галицький автономний сойм, ліквідувала місцеве самоврядування, конституція Польщі 1921 р. не передбачала права на територіяльну автономію українських земель, кресовий закон 1924 р. заборонив користуватися українською мовою в урядових установах, шкільна реформа перетворила більшість українських шкіл на двомовні, де переважала польська мова, у Львівському університеті закрили всі українські катедри. Становище українського населення ускладнювали важкі економічні умови - східні терени Польщі залишалися відсталим аграрним краєм, джерелом дешевої сировини для центральних та західних регіонів ${ }^{1}$.

Противагою важкому політичному і соціяльно-економічному становищу українців могла стати нова хвиля національного відродження. Провідниками українського руху була і залишалася українська інтелігенція, кількість і активність якої зростала (хоча і надто повільно) на початку XX ст., а після Першої світової війни значно зменшилася за рахунок активної участи в лавах УГА та вимушеної політичної еміграції повоєнного часу. Відтак основою руху і завданням

\footnotetext{
${ }^{1}$ Леонід Зашкільняк, Микола Крикун, Історія Польщі: Від найдавніших часів до наших днів (Львів: Львівський національний університет імені Івана Франка, 2002), 457-468. 
нечисленого проводу була потреба донести до широкого загалу українського суспільства, а, передусім, селянства, що складало близько 90 \% населення західноукраїнських земель ${ }^{2}$, ідею відновити українську державність.

Ступінь національної свідомости та політичної активности українського суспільства визначався рівнем освічености, нерідко умінням і бажанням долучитися до друкованого слова, кількість, якість і тематичне спрямування якого забезпечували нові та відроджені у складних умовах видавничі товариства. Саме вони взяли на себе відповідальність зберігати і поширювати культурні цінності, формувати духовний клімат, подолати песимістичні настрої, творити ідеологічні та світоглядні переконання людности. Ускладнювало справу кількавікове життя українського суспільства, за визначенням О. Пахльовської, в умовах “постійного геноциду, етноциду і лінгвоциду”з.

Масив україномовних видань міжвоєнного періоду достатньо опрацьований. В роки незалежности України укладено низку каталогів, що відображають видавничу активність культурно-просвітніх товариств, наукових організацій та окремих видавців ${ }^{4}$. Пропоноване дослідження $є$ спробою проаналізувати тематику видань двох потужних видавничих центрів, які, на наш погляд, мали великий вплив на формування свідомости української людности, що опинилася у складі Польської держави - товариства “Просвіта" та видавничого концерну "Українська Преса" підприємця Івана Тиктора.

Перші роки анексії Польською державою західноукраїнських земель поширили зневіру у власних силах, i, водночас, спонукали творців втраченої ЗахідноУкраїнської Народної Республіки до пошуків нових шляхів формувати національну свідомість українців, всебічно розширювати світогляд, духовно збагачувати й

\footnotetext{
2 Ярослав Грицак, Нариси історії Украӥни: формування модерної украӥнської наџії XIXХХ сm., (Київ: Генеза, 1996), 188.

${ }^{3}$ Оксана Пахльовська, "Українська культура у вимірі "пост": посткомунізм, постмодернізм, пост вандалізм”, Сучасність, Ч.10, (2003): отримано доступ 23 жовтня 2017, http:// www.traducionalist.info/forum/44-172-1.

${ }^{4}$ Видання Івана Тиктора та кониеерну "Українська преса”, уклад. В. Денисюк, наук. ред. Б. Якимович, (Львів, 2000), 368; Українська преса в Украӥні та світі XIX-XX ст.: Iсторикобібліографічне дослідження, уклад. М. В. Галушко, М. М. Романюк, Л. В. Сніцарчук, Т. 1, 1812 1890 рр. (Львів, 2007), 560; Т. 2, 1891-1905 рр., (Львів, 2009), 480; Т. 3, 1906-1910 рр., (Львів, 2011), 496; Украӥнські часописи Львова 1848 -1939 рр.: Історико-бібліографічне дослідження, У 3 т., Т. 3, кн. 1, 1920-1928 рр. (Львів: Світ, 2003), 910; Т. 3, кн. 2, 1929-1939 рр., 926; Літературномистецький журнал “Ми” (1933-1939): Систематичний покажчик змісту, уклад. О. Рудюк, відп. ред. Л. Сніцарчук, (Львів: ЛННБ України ім. В. Стефаника, 2011), 156; Валентина Передирій, Видання “Червоної Калини” (1922-1939): Історико-бібліографічне дослідження, (Львів: ЛННБУ ім. В. Стефаника, 2004), 357; "Сьогочасне й минуле” (1939): Систематичний покажчик змісту, уклад. В. Передирій, наук. ред. Ю. Романишин, (Львів: ЛННБУ ім. В. Стефаника, 2009), 60; Товариство "Просвіта" у Львові 1868-1939: покажчик видань, уклад. Л. Головата, Л. Сущ, О. Бербека, НАН України, Львів. наук. б-ка ім. В. Стефаника, Відділення "Наукова бібліографія і книгознавство”, 2-е вид., (Львів, 2008), 520; Наша культура, 1935-1937: систематичний покажчик змісту, упоряд. Н. Прокопенко, наук. ред. Л. Головата, (Львів: ЛННБУ ім. В. Стефаника, 2006), 124.
} 
ISSN 2078-6077. Наукові зошити історичного факультету Львівського університету. 2018-2019. Випуск 19-20. Proceedings of History Faculty of Lviv University. 2018-2019. Issue 19-20.

культурно виховувати націю. Настрої української інтелігенції відображає цитата сучасника подій Євгена Лазора "Ми боролись і - впали. Тисячами жертв цілого народу ми здобули державність i - не втримали іiі. Такий для нас вислід Першої світової війни і наших Визвольних змагань 1917-21 pр. Ми знову опинилися під ярмом, але вже не як смиренні раби, але як скривавлений і закутий велетень, що свідомий свого права і сили, скорше чи пізніше розірве кайдани і вражою злою кров'ю окропить волю. Почались під'яремні будні і з ними повседневне, повільне й уперте видужання від ран і розривання ярма... Скрізь і скрізь колишні українські вояки були провідниками, надхненниками, організаторами"5. Відповідальну місію - відстоювати національну ідею, видаючи та розповсюджуючи українську книжку у міжвоєнний період, взяли на себе культурно-просвітницькі організації, кооперативи, приватні підприємці, зокрема: "Просвіта", "Рідна Школа", "Українська Видавнича Спілка", "Русалка" Гр. Гануляка, видавнича спілка “Діло”, видавництво і випозичальня книжок “Ізмарагд”, видавництво “Чайка”, “Українська Культура”, видавничий кооператив “Червона Калина”, “Дешева Книжка” Р. Паладійчука, “Добра Книжка” М. Моха, “Світ Дитини” М. Таранька, концерн "Українська Преса” І. Тиктора та інші.

Формування особистости підприємця, впливового книговидавця, інтелектуала Івана Тиктора розпочалося в селянській родині. Він народився 6 липня 1896 р. у заможній селянській сім'ї в с. Красне Золочівського повіту (тепер Буського району Львівської області). Початкову школу закінчив у рідному селі, а далі навчався в Рогатинській українській приватній гімназії “Рідної Школи”. На початку Першої світової війни зголосився добровольцем до легіону Українських Січових Стрільців, пройшов важкими воєнними шляхами Української Галицької Армії й отримав рангу четаря. Після цього розпочав студії на правничому факультеті Львівського Таємного Університету, й водночас вступив до підпільної Української Військової Організації (УВО). За дорученням УВО 1923 р. І. Тиктор почав видавати часопис "Новий Час", який фінансувала українська діяспора США та Канади ${ }^{6}$. Проєкт виявився збитковий: зубожіле після війни українське населення Галичини не розкуповувало значну частину накладу. Вочевидь Тиктор задумується і над глибиннішими проблемами видавничих невдач: чи задовольняе тематика часопису широкі кола українського населення? Чи політичний напрям відповідає їхнім настроям? Чи вони готові до пропонованих радикалами УВО шляхів виходу з економічної та політичної кризи? Зрештою, чи він сам повністю поділяє погляди своїх роботодавців? У відповідь на ці надзвичайно складні питання 29-річний чоловік вирішує продовжити роботу самостійно, вкласти в ризикований проєкт успадковану частини батькових земель та власний

\footnotetext{
${ }^{5}$ Свген Лазор, “Розмова 3 видавцем Іваном Тиктором”, Бюлетень Клюбу Приятелів Української книжки, Ч. 3, 1952, у книзі Іван Тиктор: талан і талант, авт. кол. О. Думанська, Н. Зелінська, Л. Сніцарчук, Е. Огар, (Львів, 2007), 217.

${ }^{6}$ Ігор Чорновол, “Концерн Івана Тиктора”, Львівська газета, 8-10 липня, (2005), 7.
} 
підприємницький хист ${ }^{7}$. I, звичайно ж, необхідність учитись, удосконалювати набуті навики, звертатись до чужого досвіду. Саме так почалася співпраця 3 товариством "Просвіта", за плечима якого вже було понад 50 років видавничих пошуків. Однорічні торговельні курси при “Просвіті” стали базою знань в галузі комерційної справи, фундаментом кар'єри молодого видавця, а згодом мецената культурного, економічного та політичного життя міжвоєнної Галичини.

Пошуки і моральної, і матеріяльної підтримки в колах впливових, помірковано налаштованих кіл галицької інтелігенції засвідчують трансформацію політичних поглядів Івана Тиктора наприкінці 20-х років. У січні 1927 р. він укладає таємний договір із митрополитом Андреєм Шептицьким, згідно з яким очільник УГКЦ купує $33,3 \%$ акцій видавництва "Новий Час". Угода довгий час була утаємниченою, в чому, очевидно, були зацікавлені обидві сторони. Свідком трансакції був редактор газети Дмитро Паліїв (про це свідчить листування митрополита 3 Іваном Тиктором ${ }^{8}$ ). Співпраця виявилася довгою і плідною. Згодом видавець звертається до митрополита з проханням посприяти у кредиті від Земельного гіпотетичного банку в розмірі до 15 тисяч злотих 9 . Ці факти привідкривають завісу джерел матеріяльної допомоги підприємця, а також пояснюють зміну тематичного спрямування часопису та книжкової продукції видавничого концерну.

Окрім періодичних видань Тиктор започатковує видавати дешеві, а відтак доступні для українських селян, книжкові серії. Як додаток до газети, що став “трибуною для розвитку здорової національної творчої думки”"10, від 1924 р. він видає «Бібліотеку “Нового Часу”». Розрахована на широке коло читачів, книжкова серія складалась із науково-популярних та публіцистичних творів, оригінальної художньої літератури, спогадів та розвідок, художніх перекладів творів світової літератури. Звертають увагу видавці “Нового Часу” і на культурний та громадсько-активний рівень українських жінок: щоб зацікавити галичанок, часопис запроваджує окрему “жіночу” сторінку" .

Від 1933 р. щомісячним додатком до часопису “Наш Прапор" підприємець розпочинає випуск “Української Бібліотеки”. До 1939 р. йому вдалося донести до читача 80 книжечок за доступною для народу ціною 95 грош. Поставлену

\footnotetext{
${ }^{7}$ Богдан Якимович, “Видавець Іван Тиктор: життєвий шлях і громадська діяльність”, Україна та украӥнці: Подї далекі і близькі. Вибрані праці, Б. Якимович, (Львів, 2014), 237.

8 Ліліана Гентош, Митрополит Шептицький: 1923-1939. Випробування ідеалів, (Львів: ВНТЛ-Класика, 2015), 283.

${ }^{9}$ Там само.

${ }^{10}$ Богдан Якимович, “Видавничі засади Івана Франка в діяльності Івана Тиктора”, Україна та украӥнці: Події далекі і близькі. Вибрані прачі, 671.

${ }^{11}$ Марта Богачевська-Хом'як, Білим по білому. Жінки у громадському русі Украӥни 18841939, (Львів: Український католицький університет, 2018), 305.
} 
ISSN 2078-6077. Наукові зошити історичного факультету Львівського університету. 2018-2019. Випуск 19-20. Proceedings of History Faculty of Lviv University. 2018-2019. Issue 19-20.

мету - “...масове поширення національно-освідомлюючої й виховної лєктури” 12 реалізували, видаючи оповідання і повісті побутової та історичної тематики, воєнні спогади, гуморески, літописи подій тощо. “Українська Бібліотека” ознайомила читачів 3 творами А. Чайковського, I. Горишівського (I. Крип’якевича), Ф. Коковського, К. Гриневичевої, Л. Мосендза, І. Филипчака, І. Ольбрахта, П. Франка, Е. Яворівського, М. Гоголя, Ж. Верна, Л. Мосендза, М. Чезаре, вперше побачили світ праці наддніпрянців Д. Мордовця, Г. Журби, В. Бояринича. Окремі праці, які вийшли у книжкових серіях концерну “Українська Преса", вперше були перевидані вже у роки незалежности України, зокрема твори С. Ордівського та П. Франка ${ }^{13}$.

Бажання Тиктора пропонувати українському читачеві “такі книжки, які остануть навсе вогненними стовпами"14 гармонійно поєднались в “Історичній Бібліотеці” концерну “Українська Преса". Видання книг цієї серії засвідчили новаторські підходи підприємця і до маркетингу, і до поліграфічного виконання. Книги серії публікувалися щомісячними зшитками. Зокрема, "Велика історія України” (18 зшитків) виходила обсягом 48 сторінок, а після реалізації, виручені кошти використовували для оплати друку наступних і наступних 48 сторінок. Часом зшитки закінчувалися на половині речення чи слова ${ }^{15}$. У такий спосіб I. Тиктор опублікував “Історію українського війська" (12 зшитків) та "Історію української культури” (12 зшитків). У передмові до “Історія українського війська" видавець висловив надію, що книга “буде поученням і заохотою для дітей наших, щоб і вони підтримували та продовжували на всіх землях, де живуть і житимуть українці, визвольні змагання Нації, аж до повної перемоги" ${ }^{\prime 6}$. Сьогодні важко оцінювати інноваційні підходи Тиктора: видавці не ускладнювали собі роботу чи в такий спосіб заохочували до купівлі наступного випуску серійного видання? Незаперечний факт: видання концерну користувалися попитом i, попри низьку платоспроможність українського читача, розходилися накладами від 10 до 12 тисяч примірників ${ }^{17}$.

${ }^{12}$ Данило Мордовець, Гайдамаки: Iсторична повість, У 2 m., "Українська Бібліотека”, Ч. 1 (Львів: Накл. І. Тиктора, 1933), Т. 1, 125.

${ }_{13}^{13}$ Петро Франко, Від Стрипи до Дамаску: Пригоди четаря УСС, (Львів: Червона калина, 1992), 96; Семен Ордівський, Чорна ігуменя, (Львів: Червона Калина, 1994), 411; Семен Ордівський, Багряний хрест: Історична пригодницька повість, (Львів: Червона калина, 1992), 93.

${ }^{14}$ Які книжки читати, Наш Лемко, Ч. 4, 1 березня, (1934).

15 Зшиток V (лютий 1936 р.) закінчується реченням на с. 240: "Від другої половини XVII в., як Гетьманщина і Запорожжя”, а, відповідно, наступний зшиток VI (березень 1936 р.) розпочинається зі слів: “почали творити окремі територіяльні і військові організації, заведено також деякі різниці в титулятурі.” на с. 241. А зшиток IV (січень 1936 р.) розпочинається на с. 145 із другої частини слова "зібрання".

${ }^{16}$ Історія украӥнського війська, Клюб приятелів української книжки, (Вінніпег: Вид. І. Тиктор, 1953), 6.

${ }^{17}$ Історія украӥнської культури, під заг. ред. І. Крип'якевича, (Львів: Вид. І. Тиктора, 1937), 719; Історія украӥнського війська, під ред. І. Крип’якевича, Б. Гнатевича, (Львів: Вид. І. Тиктора, 1936), 568. 
Дещо інше призначення мала «Бібліотека "Народньої Справи”», яка почала виходити в 1929 р. (від 1937 р. «Бібліотека “Народньої Справи” “Рідне Слово”»). Книжкова серія призначалась для селян. На її сторінках друкували практичні господарські поради, обговорювали актуальні економічні проблеми. Водночас, щоб підвищувати культурно-політичний рівень селян, поміщали белетристичні твори, популярні тексти суспільно-політичної тематики (17 назв). Наприклад, М. Васьківа "У филях Бистриці: Повість”, А. Лотоцького “Триліси: Повість із козацьких часів", І. Чайківського “Обіцяна земля: Повість з нар. побуту”, Ю. Шкрумеляка “Новий вертеп”, Йова Шумського “До світла! (Сучасна повість 3 життя волинського села)”, В. Бачинського “Україна рве кайдани: Двадцятиліття української революції”, “Веселі оповідання”, О. Соколовського “Сьогоднішня Европа: Георграфічно-політичний і госп. начерк”, М. Топольницького “В чім сила народу?”, В. Бачинського “Генерал Мирон Тарнавський: Начальний Вождь УГА” та "Народний трибун: Життя і праця д-ра Свгена Олесницького", В. Гірного “Про книжку й часопис", Е. Жарського “Що таке фізична культура?", М. Семчишина "Українське письменство: Популярний нарис", М. Козака “Як списувати і провадити хроніку”, П. Мірчука "Карпатська Україна: Край, його історія і теперішній стан”, О. Охримовича “Що таке гігієна?”.

Цікаво, що книги, які користувалися попитом у різної категорії читачів творці концерну “Українська Преса" не перевидавали, як це робили просвітяни чи інші видавці. Це стосується, насамперед, львівського періоду його діяльности. Окремі праці ${ }^{18}$ Тиктор повторно або із доповненнями надрукував у Вінніпезі (Канада): серію “Історична Бібліотека", художні твори в серії “Клюб приятелів української книжки”. Вірогідно, це пов'язано із розмахом видавничої діяльности концерну "Українська Преса" у ці роки, високою ціною на матеріяли (в середині 20-х років ціна паперу зросла від трьох сотиків за аркуш до трьох марок $\left.{ }^{19}\right)$ та конкуренцією на ниві книгодрукування.

Негативний вплив на розвиток видавничої діяльности мали і постійні конфіскації друкованих видань польською владою. Загалом, протягом 1923 1939 рр. найбільше було конфісковано газетних видань концерну (“Новий Час”,

18 Леонід Мосендз, Людина покірна: Оповіді, “Клюб приятелів української книжки”, Сер. 1, Кн. 7, (Вінніпег: Вид. І. Тиктора, 1951), 144; Біч Рекс, Залізний илях: Повість з піонерського життя на Алясиі: У 2-x m., пер. $з$ англ., "Клюб приятелів української книжки”, Сер. 1, Кн. 8, 9, (Вінніпег: Вид. І. Тиктора, 1951-1952), Ч. 1., 127; Ч. 2., 132; Василь Радич, Максим Залізняк: Історичний роман: У 2-х т., “Клюб приятелів української книжки”, Сер. 1, Кн. 10, 11, (Вінніпег: Вид. Тиктор, 1952), Ч. 1., 126; Ч. 2., 126; Володимир Бірчак, Проти закону: Повість із княжих часів, “Клюб приятелів української книжки”, Сер. 2, Кн. 18, (Вінніпег: Вид. І. Тиктора, 1953), 128; Свген Яворівський, Вождь 100,000-ної армії: Пам'яті начального вождя Украӥнської Галищької Армії генерала-четаря Мирона Тарнавського: 3 приводу 20-річчя смерти, "Клюб приятелів української книжки”, Сер. 3, Кн. 22, (Вінніпег: Вид. І. Тиктора, 1958), 136.

${ }^{19}$ Просвіта до украӥнського народу, "Народня Бібліотека”, Ч. 5, (Львів: Накладом тов-ва “Просвіта", 1921), 15. 
ISSN 2078-6077. Наукові зошити історичного факультету Львівського університету. 2018-2019. Випуск 19-20. Proceedings of History Faculty of Lviv University. 2018-2019. Issue 19-20.

"Наш Прапор”, “Наш Лемко”20), що приводило до значних матеріяльних втрат. Співробітник концерну Д. Палій у листі до історика, дійсного члена НТШ, відомого публіциста М. Андрусяка (1933) писав: “Минулого тижня було 3 конфіскати за порядком! А знаєте скільки витрати приносить кожна конфіската? Кругло 500 зл [отих]!”21. I це лише одинокий приклад. Відомо також про конфіскацію книжкової продукції: праці В. Кархута “Вістря в темряві” (про це дізнаємося із нумерації чисел серії “Українська Бібліотека" та примітки до книги М. Голубця "Рік грози і надій 1914") 22, восьми сторінок оповідання I. Керницького "Святоіванські вогні”, (печатка на 20-ій сторінці) 23, сенсаційної повісті Б. Полянича “Стріл у ночі”"24 та дитячого співаника “Хлопці ж бо то, хлопці, як соколи!” (про конфіскацію останніх видань зазначено на титульних сторінках $)^{25}$. Основною причиною конфіскацій, очевидно, була тематика видань концерну.

Основний пласт займали книги про історичне минуле українських земель, визначних діячів та провідників визвольного руху, спогади очевидців революції 1917-21 pр. та “образки” з життя народу. Такі роботи високо цінували читачі, адже вони відображали реалії життя, допомагали знайти вихід із критичних ситуацій, навчали, підбадьорювали.

У репертуарі видань концерну зустрічаємо книги, де на обкладинці зазначена назва, відмінна від оригінальної. Наприклад працю М. Голубця "Слідами Хмельницького по Львові” опублікували під назвою “Хмельницький у Львові”. Практикували редактори подавати декілька творів одного автора під різними псевдонімами або додавати оповідання до чужих публікацій, не згадавши про це $^{26}$. Можливо це було помилкою видавничого колективу (Тиктора неодноразово

20 Польська влада особливо активно перешкоджала українізувати Лемківщину, відтак переслідувала Петра Смереканича - молодого редактора часопису “Наш Лемко”. Безцінний архів Смереканича віднайшов проф. Б. Якимович і передав на зберігання до відділу рідкісної та рукописної книги Наукової бібліотеки Львівського національного університету ім. Івана Франка, яку в той час очолював.

21 Листування 3 редакціями українських газет, журналів, наукових видавництв про опублікування статей, рецензій, оглядів, підготованих М. Андрусяком та їх оплату, Центральний державний історичний архів України, м. Львів, ф. 388, оп. 1, спр. 47, арк 3.

22 Василь Кархут, Вістря в темряві, “Українська Бібліотека”, Ч. 4(16)), (Львів: Накл. І. Тиктора, 1934), 127; Микола Голубець, Рік грози і надій 1914, “Українська Бібліотека”, Ч. 4(16)а), (Львів: Накл. І. Тиктора, 1934), 125.

${ }^{23}$ Іван Керницький, Святоіванські вогні: Оповідання, “Українська Бібліотека”, Ч. 6(18)), (Львів: Накл. І. Тиктора, 1934), 20, 29-126.

${ }^{24}$ Богдан Полянич, Стріл у ночі: Сензаційна повість, “Українська Бібліотека”, Ч. 42, (Львів: Накл. І. Тиктора, 1936), 128.

25 Хлопці ж бо то, хлопці, як соколи!: Співаник, «Б-ка для молоді “Ранок”», Ч. 6, (Львів: Вид. I. Тиктор, 1937), 34.

26 У 1939 р. вийшла друком книга 3 творами В. Хиляка “Лемківська доля: Повість 3 лемківського життя" під псевдонімом Єронім Анонім та оповіданням “Сипкова поляна” під псевдонімом В. Нелях. До І-ї частини повісті Д. Мордовця "Гайдамаки” додано історичний нарис М. Голубця “Гайдамаки”, а до книги І. Ольбрахта "Розбійник Микола Шугай”, у I-й частині додано нарис М. Голубця “Земля без імені”, в II-й - “Опришки”. 
критикували також за недбале ставлення до мови і стилю його видань ${ }^{27}$ ) або свідомим кроком з метою уникнути конфіскації вже надрукуваних книг, які “отуманюють тисячі читачів, - зазначають у часописі "Батьківщина" від 11 жовтня 1936 р., - деморалізує їх, присипляє їхню чуйність"28.

Як видавець, Тиктор уважно ставився до зовнішнього вигляду публікацій: “всейшов назустріч бажанням авторів у напрямі технічного оформлення книжки і дав змогу поставити ії з технічного й ілюстраційного боку на належному рівні”'29. Він дбайливо ставився до кожного проєкту, піклувався про оформлення та рекламу, пильнував, щоб усі числа серійних видань вчасно доходили до читача.

Видання Івана Тиктора i “Просвіти” художньо-технічно оформлювала плеяда талановитих львівських майстрів: Едвард Козак, Святослав Гординський, Павло Ковжун, Юрій Кірієнко, Володимир Січинський, Іван Іванець та ін. Їхні роботи відображали стилі й життєві характери митців, вони були прості для візуального сприйняття (здебільшого поєднували два або три кольори), але глибокі за змістом, вдало передавали основну ідею твору, викликали гострі емоції та зацікавленість читача ще до не прочитаного тексту. Виховувати всебічно розвинених громадян, формувати їхні естетичні смаки та культурні цінності були покликані широко репрезентовані у виданнях I. Тиктора портрети авторів, історичних постатей, визначних сучасників, а також зображення елементів побуту, військової зброї.

Окрім видавничої та редакторської праці І. Тиктор надавав фінансову допомогу культурно-просвітнім товариствам: віддавав по 1 грошу для "Рідної Школи" з окремо проданих книжок ${ }^{30}$, активно допомагав видавати популярні книжечки та періодичні видання товариству “Просвіта” (зокрема, часопис "Наш Лемко") $)^{31}$, а також кооперативному видавництву “Червона Калина" 32 , увійшовши до видавничого комітету з моменту його утворення. Від 1933 р. спостерігається співпраця I. Тиктора 3 Р. Дашкевичем, що забезпечило активну підтримку концерном "Українська Преса" спортивно-руханкового товариства “Луг” та його щомісячного друкованого органу “Вісти з Лугу"з3.

У 1931 р., коли ще більшість видавців не оговталися від економічної кризи та “пацифікації”, I. Тиктор починає видавати такий необхідний для української малечі часопис “Дзвіночок” (редактор - відомий український письменник й

27 Лишкевич С., “Рецензія на книгу: Ткачук В. Сині чічки: Нариси. Львів, 1935”, Дзвони, Ч. 1-2, (1936), 75.

${ }^{28}$ Справа по обвинуваченню відповідального редактора української газети “Українські Вісті" Гладиловича Яна за опубліковані статті, Державний архів Львівської області, ф. 11, оп. 29, спр. 7471 , арк. 10 (зв).

${ }^{29}$ Історія украӥнського війська.., 5.

${ }^{30} 1$ грош Тиктора “Рідній Школі”, Украӥнські Вісти, Ч. 218, (1938).

31 Алла Середяк, “Діяльність товариства “Просвіта” в 1929-1939 рp.” Hapuc icmopiï "Просвіти”, (Львів; Краків; Париж, 1993), 59.

32 Андрій Качор, “Червона Калина”: 60-річчя ї̈ славної видавничої діяльности, (Вінніпег, 1983), 9.

33 Зміни у видавництві І. Тиктора, Діло, Ч. 82, (1933). 
ISSN 2078-6077. Наукові зошити історичного факультету Львівського університету. 2018-2019. Випуск 19-20. Proceedings of History Faculty of Lviv University. 2018-2019. Issue 19-20.

публіцист Юрій Шкрумеляк) з бібліотечкою “Ранок”. Книжкова серія складається із 12 найменувань, які почали виходити від січня 1937 р. під редакцією Володимира Калини, фронтового старшини першого куреня УСС. Кожного місяця видавали нове число серії накладом 15 тисяч ${ }^{34}$ (відомо лише про наклад першого номера) й обсягом 32 сторінки. Твори знайомили українську молодь 3 нашою історією, рідним краєм (А. Лотоцький "Отрок князя Романа: Історичне оповідання", “Золоті Ворота”, М. Голубець “Княжий Галич”, М. Заклинський "Пізнай свій рідний край: Опис мандрівки по Карпатах"), життям братів-лемків (Ф. Коковський “Лемківська слава: Оповідання з часів татарських навал”), народними й стрілецькими піснями (“Хлопці ж бо то, хлопці, як соколи!”), звичаями і традиціями (Р. Леонтович “Сценічні образки для молоді”), основами фізичного виховання (Е. Жарський “В здоровому тілі, здорова душа: (спорт на селі)"), медичних знань (Р. Осінчук “Вороги здоровля: (Заразливі дитячі хвороби)") та здобутками і галузі технології (Е. Жарський “Повітря говорить: Оповідання про найновіші винаходи, радіо і телєвізію", С. Щурат "Учімся фотографувати: Короткий курс практ. фотографії”). Авторські праці доповнили пояснення наукових термінів, словнички давніх слів, ілюстрації, що підсилювали візуальне засвоєння текстів. Художньо-мистецьким оформленням книг займався Е. Козак, тому практично всі номери бібліотеки мають однакову двоколірну обкладинку (на тлі природи діти в українському вбранні бавляться і читають книжку). Навчально-пізнавальний характер бібліотеки для молоді "Ранок", систематичний вихід номерів, доступна ціна (30 грошів за окреме число, а в передплаті коштувало ще дешевше), великі наклади продукції, безсумнівно, відіграли чималу роль у формуванні світогляду та вихованні української дітвори. У книжковій серії, як і в попередніх, втілився підприємницький “талант” І. Тиктора: обмежена кількість сторінок (2 аркуші), популяризація книг "Ранку” та журналу “Дзвіночок”, а якщо текст перевищував норму, його додруковували на обкладинці ${ }^{35}$.

Тематика дитячих публікацій яскраво засвідчує мету видавця - твори героїчної тематики, зокрема публікації про дітей-героїв, матеріяли на релігійні теми, зокрема про потребу та способи відзначення християнських свят, вивчення побутових слів німецької та англійської мов, пісні з нотами та малюнками-рухами до них; казки, віршики та жарти для дітей різного віку. Обкладинка “Дзвіночка” незмінно зображала веселого хлопчика-козачка із дзвіночком у руці (художник талановитий митець, іконописець, карикатурист, а також редактор і видавець Едвард Козак). Часопис “Дзвіночок” та книжечки бібліотеки демонстрували високу культуру видання, що дозволило концернові впродовж восьми років випустити 94 номери часопису і 12 книжечок бібліотечки для дітей ${ }^{36}$.

\footnotetext{
${ }^{34}$ Антін Лотоцький, Отрок князя Романа: Історичне оповідання, «Б-ка для молоді “Ранок”», Ч. 1, (Львів: Вид. І. Тиктор, 1937), 32.

${ }_{35}$ Ярослав Вільшенко [А. Лотоцький], Золоті Ворота: Поема, «Б-ка для молоді “Ранок”», Ч. 11, (Львів: Вид. І. Тиктор, 1937), 34.

${ }^{36}$ Видання Івана Тиктора та кониерну “Українська преса”..., 306.
} 
У 1933 р. дитячий часопис “Дзвіночок” бере активну участь в акції громадянсько-патріотичного характеру “Даруйте книжку вбогим ровесникам”, яку організовувало товариство “Просвіта”. Видавці закликали дітей, аби вони надсилали вже прочитані книжки до товариства, а відтак їх роздарують дітям на Лемківщині та Бойківщині ${ }^{37}$.

Передовий досвід видавця й демократична орієнтація галицької еліти базувалися на твердому грунті усвідомлення етнічної і етнографічної єдности українського народу по обидва боки Дніпра. Висловлювати це відверто в тодішніх політичних умовах було небезпечно, саме тому галичани використовували літературу як засіб активізувати політичне життя й утверджувати самобутність народу.

Заслуговує на увагу “Перша лемківська читанка” (упорядник Ю. Тарнович) яка і розпочала видавничу серію «Бібліотека “Нашого Лемка”» (1934). Це був книжковий додаток до першої газети для етнічних лемків. У зверненні товариства "Просвіта" до братів-лемків в Америці в жовтні 1934 р. згадувалось: “...3 усіх українських земель найбільше грозить винародовлення Лемківщині....На Лемківщині йде нагінка на всі прояви національного українського життя" 38 . Ще до Першої світової війни українську книжку на цій території поширювали просвітяни, а від 1934 р. до них долучився також Іван Тиктор. На сторінках читанки автор розповідає про лемків, їхню території розселення, подає історію. Також, у формі коротеньких і жартівливих оповідань, інформує про важливі просвітні й господарські справи, навчає як треба працювати на культурно-просвітній ниві. У книжці підкреслено роль національної еліти в патріотичному вихованні молоді та подальшого розвитку лемків як етнічної гілки українського народу: “Нарід без рідної інтелігенції, як риба без води. Його чекає неминуча загибель... Своя інтелігенція найкраще знає потреби власного народу і краю..." ${ }^{39}$.

Ідею єдности українських земель, традиції етнографічних регіонів, колоритність місцевих проявів культури підтримує видавець друком творів Йова Шумського, У. Самчука, Ф. Коковського, 3. Кудея, Б. Шведа, В. Хиляка, П. Мірчука. У цих виданнях редакторський колектив зберігає мову оригіналу, використовує коментарі й примітки для пояснення окремих слів та доповнює роботу словничками регіональних говірок.

\footnotetext{
${ }^{37}$ Наталія Благовірна, “Впровадження принципів комерціалізації пресо- та книговидання в Галичині в першій третині XX ст. (за матеріалами журналу “Дзвіночок”)”, Поліграфія і видавнича справа, о. 39, (Львів, 2002), 41.

38 Звернення, кореспонденція до Маркіяна Дзеровича, фінансова документація, квитанції, вкладкова книжечка “Дністра”, відбитки кліше та інші матеріали редакції журналу “Наш Лемко”, Львівська національна наукова бібліотека України імені В. Стефаника. Відділ рукописів, ф. 122 (товариство "Просвіта"), спр. 21, арк. 4.

39 Перша Лемківська читанка, «Б-ка “Нашого Лемка”», Ч. 1, (Львів: Накл. І. Тиктора, 1934), 30.
} 
ISSN 2078-6077. Наукові зошити історичного факультету Львівського університету. 2018-2019. Випуск 19-20. Proceedings of History Faculty of Lviv University. 2018-2019. Issue 19-20.

Конкуруючи на ринку збуту, українські видавці робили спільну справу: долати неписьменність, розвивати культуру та національно виховувати населення Східної Галичини в умовах бездержавности. Першим товариством, яке з вибухом Першої світової війни взяло на себе тягар російської окупаційної влади, було саме товариство "Просвіта". Успіхи царської Росії на австрійському фронті в перші місяці війни сприяли нищенню ненависного новій владі “джерела мазепинства та сепаратизму”. То ж не дивно, що новоприбулий російський губернатор розпочав з ліквідації наймасовішої української організації: на початок Першої світової війни "Просвіта" налічувала 77 філій, 2944 читалень, 109950 членів товариства ${ }^{40}$. Завойовники нищили майно, палили бібліотеки, банківські документи, репресували інтелігенцію. Члени товариства, що перебували за межами окупації, не втрачали зв'язків з громадою, проводили робочі засідання, 10-тисячним накладом видали ілюстрований календар товариства на 1915 р., збірку поезій Богдана Лепкого. Головний виділ “Просвіти” активно листувався 3 воєнним міністерством у Відні про можливості розповсюдження календарів серед українських військовиків ${ }^{41}$. Однак вже у березні 1916 р. роботу вдалося відновити у Львові i, для налагодження контактів з філіями, видати часопис «Письмо з “Просвіти”» за редакцією Володимира Левицького. Однак відновити видавничу діяльність вдалося лише в 1918 р. Нові політичні обставини вимагали перегляду і видавничого репертуару, і методів розповсюдження. На пропозицію видавничої комісії Головний виділ вирішує ліквідувати обов' язкову розсилку своїх книжечок членам товариства (як це було до війни), натомість встановити для них $25 \%$ знижку. Таке новаторство просвітяни розглядали як “. .. шлях до того, щоб "Просвіта" стала дійсно видавничим товариством і своїми виданнями заповнила ринки збуту не тільки в Галичині, але й на Україні і в Америці”42

Реалії виявилися важчими, ніж уявлялися. Рік 1918 приніс різке піднесення цін на друкарську продукцію. Девальвація австрійської корони, інфляція воєнного часу привели до того, що церковні видання подорожчали на 200 \%, книжки Наукового товариства ім. Шевченка - на 100\%, "Української Видавничої Спілки" - на $50 \%{ }^{43}$. Польська влада принесла нові, не тільки матеріяльні, а й політичні негаразди. В умовах повоєнного знищення матеріяльної бази та ворожого ставлення нової адміністрації "Просвіта" оголошує конкурс на кращі воєнні спогади 1914-1920рр. Розпочату просвітянами ініціятиву згодом підхопили видавництво “Червона Калина”, “Крайове товариство охорони воєнних могил”,

\footnotetext{
${ }^{40}$ Статті, реферати та огляди про діяльність товаритсва, Центральний державний історичний архів України, м. Львів, ф. 348, оп. 1, спр. 6789, арк. 30.

41 Листування з Міністерством війни у Відні про розповсюдження календарів "Просвіта" серед військовослужбовців, Центральний державний історичний архів України, м. Львів, ф. 348, оп. 1, спр. 6512, арк. 1-2.

${ }^{42}$ Звіт з діяльності Товариства “Просвіта" у Львові за час від 8.IV.1913 до 31.XII.1920 p., (Львів, 1921), 31.

${ }^{43}$ Хроніка НТШ у Львові, Ч.60-62, (1918), 13.
} 
концерн Івана Тиктора “Українська Преса". Під керівництвом енергійного, новообраного в 1922 р., голови Івана Брика просвітяни докладають багато зусиль, щоб продавати друковані видання у сільських кооперативних крамницях. Це мало привчити українських селян до книжки, бо регулярно відвідувати львівські книгарні (яких у той час діяло тільки дві: книгарня НТШ та Ставропігійського інституту) вони не мали можливости.

Матеріяльні та організаційні перешкоди заставили видавців докладніше вивчити попит на книгу. Професор М. Возняк запропонував просвітянам нову програму, котру схвалив Головний виділ товариства. Згідно з новим планом, усі видання ділилися на 4 групи: 1. “Народна бібліотека" (популярнобелетристичного змісту) - для широкого кола читачів; 2. "Загальна бібліотека" для освіченішого читача;. 3. "Українська писемність" - видання кращих зразків літератури; 4. «Письмо 3 "Просвіти”》 - періодичний часопис товариства. М. Возняк також пропонував розпочати серію “архітворів" світової літератури в українських перекладах ${ }^{44}$, однак здійснити цей план не вдалося.

Від 1925 р. "Просвіта" почала видавати часопис “Бібліотечний порадник”, чим заповнила прогалину в рекламі і у пропаганді української книжки. Редакція пропонувала читачам “не сухий перелік книжок, але їхню оцінку, оцінку того, що книжка може дати" 45 . Допомагав часопис також збирати кошти для розпочатого в 60-ті роковини смерти Тараса Шевченка видавничого фонду “Учітеся, брати мої...".

Поступове відновлення діяльности сільських читалень привело до браку книжок у місцевих і в “мандрівних" бібліотеках товариства. Допомога надійшла і від концерну "Українська Преса" І. Тиктора, і від "Української Накладні" Я. Оренштайна (згідно з угодою "Просвіта" була єдиним представником видавництва на теренах Польщі і отримувала $45 \%$ торговельної знижки $\left.{ }^{46}\right)$.

Щоб налагодити активніший діялог з читачами, "Просвіта” організовує курси бібліотекарів (1925-1928), відкриває бібліотечну комісію при Головному виділі у Львові (1924), видає (коштом автора) книжку книгознавця і бібліографа, редактора видавництва "Всесвітня Бібліотека" (м. Золочів) Івана Калиновича "Що потрібно робити в читальнях "Просвіти": програма, розподіл та календар просвітницької праці” (1926). Серед рекомендованих бібліографом книг та часописів, окрім просвітянських, видання I. Тиктора, Я. Оренштайна та інших українських видавництв. І. Калинович наголошував на необхідності дбати не лише про кількість книжок у читальняних бібліотечках, а й на ретельному вивченні контингенту споживачів та якості розуміння прочитаних ними тем ${ }^{47}$.

\footnotetext{
${ }^{44}$ Бібліотечний порадник, Ч. 1, (1925), 16.

${ }^{45}$ Бібліотечний порадник, Ч. 2, (1925), 35.

${ }^{46}$ Степан Перський, Популярна історія товариства "Просвіта" у Львові, (Львів, 1932), 10.

${ }^{47}$ Іван Калинович, Що потрібно робити в читальнях “Просвіти”: програма, розподіл та календар просвітницької праці, (Львів: Просвіта, 1926), 3.
} 
ISSN 2078-6077. Наукові зошити історичного факультету Львівського університету. 2018-2019. Випуск 19-20. Proceedings of History Faculty of Lviv University. 2018-2019. Issue 19-20.

Аналіз тематики запотребуваних сільськими бібліотеками книг засвідчує, що найбільшим попитом користувалися книжки українських письменників, першочергово твори I. Франка, Т. Шевченка, Б. Грінченка, С. Руданського, Марка Вовчка та ін. Читацькі симпатії підтверджує тематика проданих товариством друків. Наприклад, із загальної кількости розповсюджених видань від кінця 1921-го до весни 23-го року 40\% складали щорічні календарі "Просвіти" - книжки організації побутового та господарського життя, водночас 1050 примірників оповідань Б. Грінченка, 950 - С. Руданського, $900-$ I. Котляревського, 744 - Т. Шевченка, 4 тис. портретів визначних українців ${ }^{48}$.

Вдалим маркетинговим кроком керівництва "Просвіти" була ухвала дозволити безкоштовно користуватися книжковими фондами читалень малозабезпеченим користувачам та дітям до 16 років. Кількість випозичених видань значно збільшилася, і лише економічна криза кінця 20-х років ХХ ст. привела до спаду попиту на друковане слово (див. таблиця).

\section{Статистика запитаних видань в бібліотеках "Просвіти" в 1921-1928 роках ${ }^{49}$.}

\begin{tabular}{|c|c|c|l|c|c|c|}
\hline \multirow{2}{*}{ Рік } & $\begin{array}{c}\text { Видан- } \\
\text { ня } \\
\text { україн- } \\
\text { ських } \\
\text { авторів }\end{array}$ & $\begin{array}{l}\text { Пере- } \\
\text { кладні } \\
\text { твори }\end{array}$ & $\begin{array}{l}\text { Періо- } \\
\text { дика }\end{array}$ & \multicolumn{2}{|c|}{ 3 них: } & \multirow{2}{*}{ Разом } \\
\cline { 5 - 6 } & & & $\begin{array}{c}\text { науко- } \\
\text { во- } \\
\text { попу- } \\
\text { лярні }\end{array}$ & $\begin{array}{c}\text { худож- } \\
\text { ня } \\
\text { літера- } \\
\text { тура }\end{array}$ & \\
\hline $1921-23$ & 229 & 100 & 1 & 27 & 301 & 329 \\
\hline 1924 & 1554 & 681 & 22 & 348 & 1787 & 2157 \\
\hline 1925 & 2613 & 695 & 144 & 387 & 2777 & 3452 \\
\hline 1927 & 7302 & 4366 & 204 & 664 & 1104 & 11872 \\
\hline 1928 & 5472 & 1461 & 257 & 430 & 6503 & 7190 \\
\hline
\end{tabular}

Наголосимо, що “Просвіті”, як і усім видавничим організаціям, налагодити видавничий діялог з українським читачем перешкоджала польська влада. Конфіскації вже надрукуваних і закуплених видань завдавали товариству великих матеріяльних збитків. Видавці докладали багато зусиль, щоб вчасно інформувати

48 Звіт з діяльності товариства “Просвіта” у Львові за час від 1.01.1921 до 31.03.1923 p., (Львів, 1923), 9-10.

49 Таблиця укладена на базі статистичних матеріалів, поданих у щорічних звітах товариства “Просвіта" за 1921-1928 роки, які зберігаються у Відділі україніки Львівська національна наукова бібліотека України імені В. Стефаника. 
бібліотеки та книгарні про нові цензурні обмеження. В середині 20 -х років куратор Львівської шкільної округи С. Собінський надіслав меморандум державним органам влади із закликом ліквідувати приватні українські навчальні заклади ${ }^{50}$ та методами адміністративного тиску домігся закрити велику кількість українських шкіл. У відповідь голова "Просвіти” Михайло Галущинський розробив “Проєкт працевлаштування українських безробітних інтелігентів”, що передбачав надати матеріяльну допомогу розміром 80-100 злотих як безвідсоткову позику тим, хто бажає працювати на ниві освіти українського населення Галичини ${ }^{51}$.

Економічну кризу 30-их років XX ст. болісно пережили усі культурні та видавничі організації. Відновлювати роботу доводилося навіть не з нуля: на 1931 рік борги "Просвіти" перевищували 63 тис. доларів. ${ }^{52}$ За таких обставин товариство не опускає руки, а впроваджує низку заходів для активізації контактів зі збіднілим українським читачем. Ухвалено: відмінити торгівлю з філіями, а натомість налагодити контакти безпосередньо з читальнями; зменшити торгівлю в кредит; відкрити при книгарнях пункти випозичання книжок за невелику платню ${ }^{53}$; залучати книгонош 3 виплатою їм 25 \% від виторгу ${ }^{54}$; відновити від 1934 р. випуск щомісячних книжечок обсягом 3-4 друкованих аркуші; надати пільгові умови для передплати книжок та часописів для власних читалень, кооперативів та зацікавлених організацій; розробити новий перспективний план видань. Результати активної праці вже невдовзі потішили - якщо в 1933 р. наклад видань товариства складав 74560 примірників, то в 1934-му - 175 тис. Загалом, упродовж 1934 та 1935 років “Просвіта" видала 36 назв книжок, що разом із часописом “Життя і Знання” склало майже 180 друк. аркушів. Тільки в центральній бібліотеці товариства у Львові (16897 томів без періодики на 1935 р.) впродовж 1933- 1935 рр. випозичили 12509 книжок та журналів ${ }^{55}$. Те, що "Просвіті” до кінця 1935 р. вдалося не лише вийти з економічної кризи, а й збільшити кількість читачів, красномовно засвідчує збільшення чисельности товариства до 25 тис. осіб, порівняно 314 тис. у 1934 p. ${ }^{56}$. Про готовість вести

\footnotetext{
${ }^{50}$ Меморандум куратора Львівського шкільного округу Собінського державним органам влади на Західній Україні з закликом виявляти й ліквідувати приватні українські навчальні заклади, ЦДІАУ м. Львів, ф. 348, оп. 1, спр. 243, арк. 1-3.

${ }^{51}$ Проект влаштування на роботу українських безробітних інтелігентів, ЦДІАУ м. Львів, ф. 348 , оп. 1 , спр. 248 , арк. 1.

${ }^{52}$ Степан Перський, Популярна історія товариства “Просвіта" у Львові..., 111.

53 Проект заходів для покращення планування роботи і діловодства книгарні, складений ревізійною комісією товариства, ЦДІАУ м. Львів, ф. 348, оп. 1, спр. 6669, арк. 1-2.

${ }^{54}$ Газетні статті про видавничу діяльність товариства, ЦДІАУ м. Львів, ф. 348, оп. 1, спр. 6801 , арк. 7.

${ }^{55}$ Товариство "Просвіта" в роках 1933-1935, (Львів: Просвіта, 1936), 17, 59.

${ }_{56}$ Йдемо вперед. Огляд праці “Просвіти” в останніх роках, Народний ілюстрований календар “Просвіти” на переступний рік 1936, (Львів: Просвіта, 1935), 67.
} 
ISSN 2078-6077. Наукові зошити історичного факультету Львівського університету. 2018-2019. Випуск 19-20. Proceedings of History Faculty of Lviv University. 2018-2019. Issue 19-20.

діялог з українською громадою на серйозні суспільно-політичні теми засвідчує зміна тематики видань для народу: окрім популярних викладів на історичні та господарські теми з'являються грунтовні студії з географії (В. Кубійович “Територія і населення українських земель”, 1935 р.), природознавства (О. Терлецький “Вплив природи на історію України”, 1936 р.), членські книжечки знайомлять читача з історією самовизначення народів світу (Б. Галайчук "Про Грузію та грузинів. Як грузини волі добивалися”, “Боротьба сьогочасних греків за волю”, 1936 р., 1939 р.; І. Брик “Боротьба чехів за волю”, 1937 р.). Очевидно, не всі верстви українського суспільства були готові сприймати серйозні теми, науково обгрунтовані виклади, однак зміна тематики засвідчує бажання видавців не просто задовольняти, а й формувати читацькі інтереси українців Галичини.

Спільним у діяльності “Просвіти” та концерну І. Тиктора було бажання знайти читача в українських Карпатах. Польська влада використовувала адміністративні заходи, що значно ускладнювало роботу культурно-просвітніх організацій. Лемківський регіон перевели з Львівського до Краківського судового підпорядкування, греко-католицькі парохії вивели з підпорядкування Львівської митрополії, разом із забороною діяльности лемківської комісії при Головному виділі “Просвіти” майже усі читальні Новосанецької філії в середині 30 -х років ліквідували. За таких обставин розповсюдити свій вплив на Лемківщину "Просвіта" змогла лише від 1932 до 1936 року. Однак її внесок у ліквідацію неписьменності регіону є беззаперечним. У важкі покризові роки на культурні потреби лемків з бюджету товариства затратили: в 1933 р. - 608 золотих, в 1934 - 1006, у 1935 - 2500, в 1936 - 340057. Саме на кошти філії “Просвіти” Іван Тиктор видає та розповсюджує періодичний часопис "Наш Лемко”, який користувався попитом і разом з іншими виданнями слугував джерелом національної самоідентифікації регіону (впродовж 1932 р. на Лемківщині вдалося розповсюдити 3112 прим. українофільських видань та 250 прим. періодики москвофільського спрямування $\left.{ }^{58}\right)$.

У 1938 році просвітяни планують втілити давню мрію - відкрити у Львові Інститут освіти, “де наша інтелігентна молодь готувала б себе до повсякденної праці для народу" 59 . Базою, очевидно, слугували прибутки товариства, які на 1939 р. значно перевищували видатки (238 проти 182 тис. злотих ${ }^{60}$ ). Втілити амбітні мрії завадила Друга світова війна. Доля видавничого концерну Івана Тиктора, "Просвіти” та інших українських товариств була однаковою більшовицький режим не пробачив їх ролі у формуванні національного світогляду людей, які здобували навики цивілізованого господарювання, прилучалися до надбань світової культури. Тисячі активістів пройшли через пекло радянського

57 Львівська національна наукова бібліотека України імені В. Стефаника. Відділ рукописів, ф. 122 (Товариство “Просвіта”), спр. 17, п.1, с. 2.

58. Там само, спр., п.1, с.1.

${ }^{59}$ Товариство “Просвіта" в роках 1936-1938 (Львів: Просвіта, 1939), 81.

${ }^{60}$ Сторіччя матері “Просвіти” 1968-1968, (Вінніпег, 1968), 285. 
ГУЛАГу, українські видання, рукописи, архівні матеріяли нищилися, не залежно від змісту та тематичного спрямування.

Підсумуємо. Українська інтелігенція в міжвоєнний період, незалежно від приналежности до просвітницької, політичної чи господарської організації, цілеспрямовано працювала над ліквідацією неграмотности українського люду, що після розпаду Австро-Угорщини і поразки Визвольних змагань потрапив під владу Польської держави. Зберегти власну ідентичність можна було, налагодивши тісний діялог з усіма верствами суспільства, доносячи друковане слово до кожної української родини. Складність завдання полягала, насамперед, щоб подолати матеріяльні злидні, спричинені повоєнною руїною та економічними кризами, а відтак у необхідности сформувати і задовольнити інформаційні потреби суспільства.

Спільними діями для “Просвіти”, видавничого концерну “Українська Преса" I. Тиктора були: ретельний підбір тематики видань для народу; доступність ціни на книжки чи часописи i, водночас, ілюстративність видання; пошуки та реалізація нових способів книгорозповсюдження, вигідних для читача у найвіддаленіших від Львова куточках; меценатство, не зважаючи на власні матеріяльні труднощі (проєкти “Даруйте книжку вбогим ровесникам Лемківщини”), наголос на вшануванні Визвольних змагань 1914-1920 pр. (конкурс на кращі воєнні спогади “Червона Калина”, “Крайове товариство охорони воєнних могил”, концерн Івана Тиктора).

\title{
PUBLISHING DIALOGUE WITH UKRAINIAN SOCIETY UNDER POLISH AUTHORITY (FOR EXAMPLE OF ISSUES OF IVAN TYKTOR AND SOCIETY "PROSVITA")
}

\author{
Maria PIRKO, Alla SEREDIAK \\ Ivan Franko National University of Lviv, \\ Department of Local History \\ Universytetska str. 1, 79000, Lviv, Ukraine \\ mariya.pirko@gmail.com,_aserediak@yahoo.com
}

The failure of the liberation struggle of the 1914-1920s challenged the Ukrainian intelligentsia with difficult tasks: to bring out the population of a difficult material and moral crisis, to restore faith in their own forces, to continue the struggle for their own independent state. The way to saving their own identity under the authority of the Second Republic of Poland was through the establishment of a narrow dialogue with all parts of the society. Understanding could be achieved by bringing a printed word to each town, village, and every Ukrainian family. It became the main task of national societies that began to work during Ukrainian-Polish confrontation or resumed their activities after the collapse of Austrî-Hungarian Empire. The article is an attempt to analyze the issues of the editions of two powerful publishing centers, the society of "Prosvita" and the publishing activity of Ivan Tyktor at "Ukrainian Press", which, in our opinion, had a great influence on the formation of the consciousness of the Ukrainian people who was found themselves under Polish rule. 
ISSN 2078-6077. Наукові зошити історичного факультету Львівського університету. 2018-2019. Випуск 19-20. Proceedings of History Faculty of Lviv University. 2018-2019. Issue 19-20.

Material and organizational problems forced publishers to learn in detail the demand for a printed word, to select the subject of publications more carefully, to find the best ways to submit the material, and to improve the book distribution system. Publishing products were divided into book series, depending on the age, level of education and daily needs of the reader. At the same time, for all categories, emphasis was placed on historical subjects, in particular, the commemoration of the liberation struggle of 1914-1920 and the memoires of the participants. Despite the desire to cheapen magazines and books, publishers took care of artistic design of printed matter, enriched texts with illustrative material. Such approach allowed to increase the number of consumers, publications, and to raise the popularity of Ukrainian books among the people.

Ivan Tyktor, the talented entrepreneur, used the original marketing moves to spread his own products: he reduced the circulation to certain standards, cut out parts of the works (sometimes ending the issue at half of the sentence), changed the names of national patriotic books to avoid confiscation from the authority, etc. The members of "Prosvita" regularly arranged "holiday books", fairs, rewards for interesting newsletters from poor readers and children under 16, introduced a new form of distribution - "traveling libraries", opened new cells in the most remote corners of Eastern Galicia.

The publishing houses suffered from an economic crisis of the 1930-s: they had to look for new ways of financing, new methods to intensify contacts with the impoverished Ukrainian reader. In spite of their own material difficulties, the publishers were engaged in patronage (the project "Give a Book to the Poor Peers" in Lemkivshchyna and Boykivshchyna, providing material assistance to educators, etc.).

The Polish authority prevented a publishing dialogue with the Ukrainian reader. The confiscation of already printed and purchased books caused a great deal of material damage. Apparently, the main reason of the confiscations was the subject of printed materials.

So, in the interwar period the Galician publishers carefully searched the best ways to reach the reader and by the end of the 30-s of XX century they succeeded in it. Beside the popular publications on historical and economic topics, they offered deep research on geography, natural science, translations of works of the world classics, not only to satisfy but to shape the tastes of Ukrainian people.

Key words: society of "Prosvita", Ivan Tyktor, "Ukrainian Press", ukrainian issues, national conscionesss.

\section{REFERENCES}

Bibliotechnyi poradnyk, No. 1, (1925). (in Ukrainian)

Bibliotechnyi poradnyk, No. 2, (1925). (in Ukrainian)

Bich, Reks. Zaliznyi shlyiakh: Povist z pionerskoho zhyttia na Aliastsi: U 2 t., per. z anhl., "Kliub pryiateliv ukrainskoi knyzhky", Ser. 1, Kn. 8, 9, (Vinnipeg: Vyd. I. Tyktora, 19511952), T. 1., 127 s.; T. 2., 132 s. (in Ukrainian)

Birchak, Volodymyr. Proty zakonu: Povist iz kniazhykh chasiv, "Kliub pryiateliv ukrainskoi knyzhky”, Ser. 2, Kn. 18, (Vinnipeg: Vyd. I. Tyktora, 1953), 128 s. (in Ukrainian)

Blahovirna, Nataliia. "Vprovadzhennia pryntsypiv komertsializatsii preso- ta knyhovydannia v Halychyni v pershii tretyni XX st. (za materialamy zhurnalu "Dzvinochok")", Polihrafiia i vydavnycha sprava, No. 39, (Lviv, 2002), 37-43. (in Ukrainian)

Bohachevska-Xomiak, Marta. Bilym po bilomu. Zhinky u hromadskomu rusi Ukraiiny 18841939, (Lviv: Ukraiinskyi katolytskyi universytet, 2018), 305 s. (in Ukrainian)

Chornovol, Ihor. "Kontsern Ivana Tyktora", Lvivska hazeta, 8-10 lypnia, (2005), 7 s. (in Ukrainian)

Franko, Petro. Vid Strypy do Damasku: Pryhody chetaria USS, (Lviv: Chervona Kalyna, 1992), 96 s. (in Ukrainian)

Hazetni statti pro vydavnychu diialnist tovarystva, Centralnyi derzhavnyi istorychnyi arkhiv Ukrainy, m. Lviv, f. 348, op. 1, spr. 6801, 40 ark. 
ISSN 2078-6077. Наукові зошити історичного факультету Львівського університету. 2018-2019. Випуск 19-20. Proceedings of History Faculty of Lviv University. 2018-2019. Issue 19-20.

Hentosh, Liliana. Mytropolyt Sheptytskyi: 1923-1939. Vyprobuvannia idealiv, (Lviv: VNTLKlasyka, 2015), 283 s. (in Ukrainian)

Holubets, Mykola. Rik hrozy i nadii 1914, "Ukrainska Biblioteka”, Ch. 4(16)a), (Lviv: Nakl. I. Tyktora, 1934), 125 s. (in Ukrainian)

Hrytzak, Yaroslav. Narysy istorii Ukrainy: formuvannia modernoi ukrainskoi nacii XIX-XX st., (Kyiv: Heneza, 1996), 360 s. (in Ukrainian)

Istoriia ukrainskoho viiska, Kliub pryiateliv ukrainskoi knyzhky, (Vinnipeg: Vyd. I. Tyktor, 1953), 832 s. (in Ukrainian)

Istoriia ukrainskoho viiska, pid red. I. Krypiakevycha, B. Hnatevycha, (Lviv: Vyd. I. Tyktora, 1936), 568 s. (in Ukrainian)

Istoriia ukrainskoi kultury, pid zah. red. I. Krypiakevycha, (Lviv: Vyd. I. Tyktora, 1937), 719 s. (in Ukrainian)

Kachor, Andrii “Chervona Kalyna”: 60-richchia ii slavnoi vydavnychoi diialnosti, (Vinnipeg, 1983), 24 s. (in Ukrainian)

Kalynovych, Ivan. Shcho potribno robyty v chytalniakh "Prosvity": programa, rozpodil ta kalendar prosvitnytskoi pratsi, (Lviv: Prosvita, 1926), 3. (in Ukrainian)

Karkhut, Vasyl. Vistria v temriavi, "Ukrainska Biblioteka”, Ch. 4(16), (Lviv: Nakl. I. Tyktora, 1934), 127 s. (in Ukrainian)

Kernytskyi, Ivan. Sviatoivanski vohni: Opovidannia, "Ukrainska Biblioteka”, Ch. 6(18), (Lviv: Nakl. I. Tyktora, 1934), 20, 29-126 s. (in Ukrainian)

Khloptsi zh bo to, khloptsi, iak sokoly!: Spivanyk, «B-ka dlia molodi "Ranok”», Ch. 6, (Lviv: Vyd. I. Tyktor, 1937), 34 s. (in Ukrainian)

Khronika NTSh u Lvovi, Vol. 60-62, (1918), 13. (in Ukrainian)

Lazor, Yevhen "Rozmova z vydavtsem Ivanom Tyktorom”, Biuleten Kliubu Pryiateliv Ukrainskoi knyzhky, No. 3, 1952, u knyzi Ivan Tyktor: talan i talant, avt. kol. O. Dumanska, N. Zelinska, L. Snitsarchuk, E. Ohar, (Lviv, 2007), 217 s. (in Ukrainian)

Literaturno-mystetskyi zhurnal "My" (1933-1939): Systematychnyi pokazhchyk zmistu, uklad. O. Rudyuk, vidp. red. L. Snitsarchuk, (Lviv: LNNB Ukrainy im. V. Stefanyka, 2011), 156 s. (in Ukrainian)

Lototskyi, Antin. Otrok kniazia Romana (istorychne opovidannia), «B-ka dlia molodi “Ranok”», Ch. 1, (Lviv: Vyd. I. Tyktor, 1937), 32 s. (in Ukrainian)

Lyshkevych S., "Retsenziia na knyhu: Tkachuk V. Syni chichky: Narysy. Lviv, 1935”, Dzvony, No. 1-2, (1936), 74-75. (in Ukrainian)

Lystuvannia z redakciiamy ukraiinskykh hazet, zhurnaliv, naukovykh vydavnytstv pro opublikuvannia statei, retsenzii, ohliadiv, pidhotovanykh M. Andrusiakom ta ikh oplatu, Centralnyi derzhavnyi istorychnyi arkhiv Ukrainy, m. Lviv, f. 388, op. 1, spr. 47. (in Ukrainian)

Lystuvannyia z Ministerstvom viiny u Vidni pro rozpovsiudzhennia kalendariv "Prosvita" sered viiskovosluzhbovciv, Centralnyi derzhavnyi istorychnyi arkhiv Ukrainy, m. Lviv, f. 348, op. 1, spr. 6512, 2 ark. (in Ukrainian)

Memorandum kuratora Lvivskoho shkilnoho okruhu Sobinskoho derzhavnym orhanam vlady na Zakhidnii Ukraini z zaklykom vyiavliaty i likviduvaty pryvatni ukrainski navchalni zaklady, Centralnyi derzhavnyi istorychnyi arkhiv Ukrainy, m. Lviv, f. 348, op. 1, spr. 243, 3 ark. (in Ukrainian)

Mordovets, Danylo. Haidamaky: Istorychna povist, U 2 t., "Ukraiinska Biblioteka”, T. 1 (Lviv: Nakl. I. Tyktora, 1933), 125 s. (in Ukrainian) 
ISSN 2078-6077. Наукові зошити історичного факультету Львівського університету. 2018-2019. Випуск 19-20. Proceedings of History Faculty of Lviv University. 2018-2019. Issue 19-20.

Mosendz, Leonid. Liudyna pokirna: Opovidi, "Kliub pryiateliv ukrainskoi knyzhky”, Ser. 1, Kn. 7, (Vinnipeg: Vyd. I. Tyktora, 1951), 144 s. (in Ukrainian)

Nasha kultura, 1935-1937: systematychnyi pokazhchyk zmistu, uporyad. N. Prokopenko, nauk. red. L. Holovata, (Lviv: LNNBU im. V. Stefanyka, 2006), 124 s. (in Ukrainian)

Ordivskyi, Semen. Bahrianyi khrest: Istorychna pryhodnytska povist, (Lviv: Chervona Kalyna, 1992), 93 s. (in Ukrainian)

Ordivskyi, Semen. Chorna ihumenia, (Lviv: Chervona Kalyna, 1994), 411 s. (in Ukrainian)

Pakhlovska, Oksana. "Ukrainska kultura u vymiri "post": postkomunizm, postmodernizm, post vandalizm", Suchasnist, Vol.10, (2003). http://www.traducionalist.info/forum/44-172-1. (in Ukrainian)

Peredyrii, Valentyna. Vydannia “Chervonoi Kalyny”" (1922-1939): Istoryko-bibliohrafichne doslidzhennia, (Lviv: LNNBU im. V. Stefanyka, 2004), 357 s. (in Ukrainian)

Persha Lemkivska chytanka, «B-ka "Nashoho Lemka”», Ch. 1, (Lviv: Nakl. I. Tyktora, 1934), 64 s. (in Ukrainian)

Perskyi, Stepan. Populiarna istoriia tovarystva "Prosvita" u Lvovi, (Lviv, 1932), 268 s. (in Ukrainian)

Polianych, Bohdan. Stril u nochi: Senzatsiina povist, "Ukrainska Biblioteka”, Ch. 42, (Lviv: Nakl. I. Tyktora, 1936), 128 s. (in Ukrainian)

Proekt vlashtuvannia na robotu ukrainskykh bezrobitnykh intelihentiv, Centralnyi derzhavnyi istorychnyi arkhiv Ukrainy, m. Lviv, f. 348, op. 1, spr. 248, 3 ark. (in Ukrainian)

Proekt zakhodiv dlia pokrashchennia planuvannia roboty i dilovodstva knyharni, skladenyi reviziinoiu komisiieiu tovarystva, Centralnyi derzhavnyi istorychnyi arkhiv Ukrainy, m. Lviv, f. 348, op. 1, spr. 6669, 2 ark. (in Ukrainian)

Prosvita do ukrainskoho narodu, "Narodnia Biblioteka", Ch. 5, (Lviv: Nakladom tov-va "Prosvita", 1921), 15 s. (in Ukrainian)

Radych, Vasyl. Maksym Zalizniak: Istorychnyi roman: U 2 t., "Kliub pryiateliv ukrainskoi knyzhky”, Ser. 1, Vol. 10, 11, (Vinnipeg: Vyd. Tyktor, 1952), T. 1., 126 s.; T. 2., 126 s. (in Ukrainian)

Serediak, Alla. "Diialnist tovarystva "Prosvita” v 1929-1939" Narys istorii "Prosvity", (Lviv; Krakiv; Paryzh, 1993), 63 s. (in Ukrainian)

"Sohochasne i mynule" (1939): Systematychnyi pokazhchyk zmistu, uklad. V. Peredyrii, nauk. red. Yu. Romanyshyn, (Lviv: LNNBU im. V. Stefanyka, 2009), 60 s. (in Ukrainian)

Sprava po obvynuvachenniu vidpovidalnoho redaktora ukrainskoi hazety" "Ukrainski Visti" Hladylovycha Yana za opublikovani statti, Derzhavnyi arkhiv Lvivskoi oblasti, f. 11, op. 29, spr. 7471, 104 ark. (in Ukrainian)

Statti, referaty ta ohliady pro diialnist tovarytsva, Centralnyi derzhavnyi istorychnyi arkhiv Ukrainy, m. Lviv, f. 348, op. 1, spr. 6789, 105 ark. (in Ukrainian)

Storichchia materi "Prosvity" 1968-1968, (Vinnipeg, 1968), 285 s. (in Ukrainian)

Tovarystvo "Prosvita" u Lvovi 1868-1939: pokazhchyk vydan, uklad. L. HHHjklllolovata, L. Sush, O. Berbeka, NAN Ukrayiny, Lviv. nauk. b-ka im. V. Stefanyka, Viddilennia "Naukova bibliohrafiia i knyhoznavstvo", 2-e vyd., (Lviv, 2008), 520 s. (in Ukrainian)

Tovarystvo "Prosvita" v rokakh 1933-1935, (Lviv: Prosvita, 1936), 59 s. (in Ukrainian)

Tovarystvo "Prosvita" v rokakh 1936-1938 (Lviv: Prosvita,1939), 81 s. (in Ukrainian)

Tovarystvo "Prosvita". Lvivska natsionalna naukova biblioteka Ukrainy imeni V. Stefanyka. Viddil rukopysiv, f. 122, spr. 17, p.1, 2 s. (in Ukrainian) 
ISSN 2078-6077. Наукові зошити історичного факультету Львівського університету. 2018-2019. Випуск 19-20. Proceedings of History Faculty of Lviv University. 2018-2019. Issue 19-20.

Ukrainski chasopysy Lvova 1848-1939: Istoryko-bibliohrafichne doslidzhennia, U 3 t., T. 3 , Kn. 1, 1920-1928, (Lviv: Svit, 2003), 910 s.; T. 3, kn. 2, 1929-1939, 926 s. (in Ukrainian)

Ukrayinska presa v Ukraini ta sviti XIX-XX st.: Istoryko-bibliohrafichne doslidzhennia, uklad. M. V. Halushko, M. M. Romanyuk, V. Snitsarchuk, T. 1, 1812-1890, (Lviv, 2007), 560 s.; T. 2, 1891-1905, (Lviv, 2009), 480 s.; T. 3, 1906-1910, (Lviv, 2011), 496 s. (in Ukrainian)

Vilshenko, Yaroslav. Zoloti Vorota: Poema, «B-ka dlia molodi “Ranok”», Vol. 11, (Lviv: Vyd. I. Tyktor, 1937), 34 s. (in Ukrainian)

Vydannia Ivana Tyktora ta kontsernu "Ukrainska pressa", uklad. V. Denysiuk, nauk. red. B. Yakymovych, (Lviv, 2000), 368 s. (in Ukrainian)

Yaki knyzhky chytaty, Nash Lemko, N.4, 1 bereznia, (1934). (in Ukrainian)

Yakymovych, Bohdan, "Vydavnychi zasady Ivana Franka v diyalnosti Ivanà Tyktora", Ukraina ta ukrainci: Podiii daleki i blyzki. Vybrani pratsi, 671 s. (in Ukrainian)

Yakymovych, Bohdan. "Vydavets Ivan Tyktor: zhyttievyi shliach i hromadska diialnist", Ukraina ta ukrainci: Podii daleki i blyzki. Vybrani pratsi, B. Yakymovych, (Lviv, 2014), 237 s. (in Ukrainian)

Yavorivskyi, Yevhen. Vozhd 100000-noi armii: Pam'iati nachalnoho vozhdia Ukrainskoi Halytskoi Armii henerala-chetaria Myrona Tarnavskoho: Z pryvodu 20-richchia smerty, "Kliub pryiateliv ukrainskoi knyzhky”, Ser. 3, Kn. 22, (Vinnipeg: Vyd. I. Tyktora, 1958), 136 s. (in Ukrainian)

Ydemo vpered. Ohliad pratsi "Prosvity" v ostannikh rokakh, Narodnyi iliustrovanyi kalendar "Prosvity" na perestupnyi rik 1936, (Lviv: Prosvita, 1935), 67 s. (in Ukrainian)

Zashkilniak, Leonid. Krykun, Mykola. Istoriia Polshchi: Vid naidavnishykh chasiv do nashykh dniv. (Lviv: Lvivskyi nacionalnyi universytet imeni Ivana Franka, 2002), 752 s. (in Ukrainian)

Zminy u vydavnytstvi I. Tyktora, Dilo, No. 82, (1933). (in Ukrainian)

Zvit z diialnosti tovarystva "Prosvita" u Lvovi za chas vid 1.01.1921 do 31.03.1923, (Lviv, 1923), 35 s. (in Ukrainian)

Zvit z diialnosti Tovarystva "Prosvita" u Lvovi za chas vid 8.IV.1913 do 31.XII.1920, (Lviv, 1921), 31 s. (in Ukrainian)

1 grosh Tyktora “Ridnii Shkoli”, Ukrainski Visty, No. 218, (1938). (in Ukrainian) 